Valóságos könyvtár - könyvtári valóság. Könyvtár- és információtudományi tanulmányok 2020. Szerk. Kiszl Péter, Boda Gáborné Köntös Nelli.

Budapest, ELTE BTK Könyvtár- és Információtudományi Intézet. 2021. 413-420.

\title{
TRANSZFEREK ÉS A KÖNYVTÁR SZEREPE A FELSŐOKTATÁS ÉS A CÉGES SZEKTOR KAPCSOLATÁBAN
}

\author{
NEMES LÁSZLÓ \\ Magyar Információtudományi Alapítvány, elnök
}

\section{TARTALMI ÖSSZEFOGLALÓ}

A felsőoktatási intézmények egyrészt a már meglévő tudomány-, illetve szakterületi tudásvagyont örökítik tovább a következő diplomás, illetve kutatónemzedék számára, másrészt újat állítanak elő. A felsőoktatás sajátossága, hogy nem kizárólag az oktatás és a kutatás révén van kapcsolata más társadalmi rendszerekkel és szereplőkkel. A harmadik missziónak hívott feladat, illetve tevékenységkör is mérhetően fontossá vált. Ebben összefoglalóan magában értjük azokat a tevékenységeke, hatásokat, amelyeket nem az akadémiai partnerekkel való kapcsolat, valamint az elóbb felsorolt első két feladat során végeznek az intézmények, egyebek mellett a szellemi tulajdon hasznosítását és a jogok átadását, vagy a helyi, illetve országos szakpolitikák formálásához való hozzájárulást ugyanúgy, mint a lokális közösségekre gyakorolt gazdasági és társadalmi, valamint kulturális hatást, illetve szolgáltatásokat. A felsőoktatási intézmények szervezeti egységei közül a könyvtár az, amely mindhárom feladathoz szorosan kapcsolódhat, hiszen jelen van a képzésben, hátteret biztosít a kutatásokhoz és azok eredményeinek disszeminációjához, és emellett a nem egyetemi polgárok által ez a legkönnyebben elérhetô intézményi szolgáltatás. Ez azért is különösen fontos, mert az egyetemek sikerének - nem csak teljesítményének - egyik kulcsa a megfelelő színvonalú transzfer folyamatkezelés.

A DIKW-piramis (Data-Information-Knowledge-Wisdom Pyramid) első három szintje (az adat, az információ és a tudás) esetében a felsőoktatási folyamatok mindegyikében állít elő új terméket. Kérdés, hogy az oktatás és a kutatás mennyire képes ezen termékek társadalmiasítására, és milyen transzfer folyamatok léteznek? E kérdés feltevésekor el kell különíteni az intézmények reklám, illetve PR tevékenységét azoktól a transzfer folyamatoktól, amelyek a tudásvagyon alkotó elemeiből tevődnek össze. A vizsgált hazai, illetve nemzetközi intézményi gyakorlat alapján a szerző összegzi a lehetséges megoldásokat.

Ma már nem kérdés, hogy az információval gazdálkodunk, hogy adatokat hasznosítunk és hogy tudást nemcsak megszerzünk, hanem folyamatosan fejlesztünk is, különben elavul. Mindezekben óriási szerepe van a - tudomány és gazdaság jelentős részén immár természetes(nek tekintett) módon jelenlévő - digitalizációnak, amelynek következtében 


\section{NEMES LÁSZLÓ}

az 1970/80-as évektől ismert eljárások váltak megvalósíthatóvá. A keresési folyamatok gyorsabbá váltak, a hitelesség kérdése is egyre inkább előtérbe helyeződik, hiszen korábban több idő állt rendelkezésre annak ellenőrzésére. Az analóg időszakban nem létező elektronikus információ-, illetve adatáradat alakult, amely a megnövekedett elektronikus dokumentáltságból és automatizáltság által termelt adatmennyiségből fakad. Mindez nemcsak a hétköznapi életünkre, hanem a szervezetek - legyen szó felsőoktatási intézményről, gazdasági társaságról vagy magának az államnak a szervezeteirôl - múködésére, illetve a kutatás-fejlesztés folyamataira is érvényes.

Miért foglal el különleges helyet a felsőoktatás az adat, az információ, illetve a tudástranszfer szempontjából? A helyzete azért speciális, mivel az oktatási szektor azon területét jelenti, amelyben az intézmények önálló és komplex rendszerként az oktatási és kutatási egységek mellett ún. harmadik missziót (third mission) ${ }^{1}$ végző szervezeti egységekkel (elsődlegesen könyvtári szolgáltatásokat nyújtókkal) is rendelkeznek. A felsőoktatás nemcsak a már létező tudást adja át, illetve az információ tudássá alakításának készségét fejleszti, hanem kutatási tevékenysége folytán adatokkal is dolgozik, azok előállítása, valamint értelmezése révén. Az egyetemi szektortól a gazdasági szereplők irányába áramló tudás jelentős gazdasági potenciállal rendelkezik, ugyanakkor sok tényező függvénye, annak kibontakozási hatékonysága, egyebek mellett a kapcsolat minőségétől, a kutatók e hálózatokban betöltött szerepétől függ. ${ }^{2}$

Kutatásom fókuszában a bölcsész- és humántudományi képzésekhez kapcsolódó folyamatok állnak, amelyek más tudományterületekhez képest kevésbé feltártak. Azt már most le kell szögezni, hogy a hazai és külföldi felsőoktatási intézmények szervezeti felépítése és múködése is olyan, hogy nem minden folyamat különíthető el egy-egy képzési területre, vagy szervezeti egységre vonatkozóan.

A téma vizsgálatának aktualitása három szempontból indokolható:

1. A felsőoktatás és a céges szektor közötti információ- és tudásáramlási folyamatok kiemelt jelentőséggel bírnak egy ország $\mathrm{K}+\mathrm{F}+\mathrm{I}$ teljesítménye szempontjából.

2. A digitalizáció átalakítja a felsőoktatás elsődleges (oktatási), másodlagos (kutatási és fejlesztési), valamint harmadik missziós szerepeit is.

3. A bölcsészettudományi képzési területet e modellekben eddig nem vizsgálták. A Valóságos könyvtár - könyvtári valóság IV. konferencián tartott előadásomban az alábbi kérdésekre kerestem a választ:

1. Milyen intézményi-céges kapcsolatok léteznek általában és a vizsgált bölcsészettudományi karokon?

2. Mit jelent a digitális transzformáció az oktatás és a kutatás terén?

Napjainkra azon országok esetében, ahol az adat, az információ és a tudás mint alapanyag, illetve mint termék van jelen, mind a gazdasági, mind a kutatási szektor szereplői esetében a felsőoktatás és az üzleti szektor kapcsolatának vizsgálata a könyvtár- és információtudomány oldaláról is legitim kérdéskörré vált. A felsőoktatási és a magánszféra közti információáramlási rendszerek feltártsága tudományterületenként igen eltérő. 
Az innovációs folyamatok erősödése révén a három szereplő (állam - piac szakma) egymáshoz való viszonya megváltozott a Clark-féle triple helix modell 1980as éveket tükröző alapfelállásához képest. Ez Magyarországra különösen igaz, ahol a rendszerváltozást követően az addig gyakorlatilag nem létező magánszektor létrejött, és az ezredfordulót követően kialakult start-up fejlesztési és innovációs láz felpörgette a különböző méretű vállalkozások működését. A versenyképességet alapjaiban meghatározó innovációs rendszer egyik legfontosabb részét a felsőoktatási szektor alkotja, amely azonban nem saját belső autonóm szabályozási rendszere szerint múködik. Az állam által meghatározott akkreditációs, szabályozási és a fenntartói kérdésekben (az intézmények közel 40\%-ban, a hallgatói és oktatói létszámot tekintve több mint kétharmadában) az állam a döntéshozó. Ennek következtében a három szektor között egyfajta függőség alakult ki. A vállalkozói szektornak előnye származik abból, ha kooperál a felsőoktatási intézményekkel, ezért érdekeltté vált a kapcsolatok kialakításában. Az együttmúködés nemcsak mikro-, hanem makrogazdasági szinten is haszonnal jár, ezért az állam is érdekelt ezek támogatásban. A felsőoktatási intézmények viszont azzal szembesülnek, hogy hiába növekszik az állami szabályozás mértéke, a források nem biztosítják a folyamatos fejlesztésekhez szükséges tőkét, amelyeket viszont projektek révén a magánszektorból - elsősorban az ipari szereplőktől - be tudnak szerezni, ezért ők is nyitnak az üzleti szektor felé.

Természetesen ez a folyamat nem csak Magyarországon figyelhető meg. A vállalkozó egyetem modellje az észak-európai országokban (e tekintetben Észtország is ide sorolandó) is meghonosodott. Finnországban a Helsinki Egyetem, Észtországban a Tartui Egyetem klasszikus tudományegyetemként a felsőoktatási elvárásoknak megfelelően működik, míg a többi egyetem ellépett a szolgáltatói egyetemi modell felé, azaz kutatásaikat a magánszektor felől érkező megrendeléseknek megfelelően orientálják. A kulcsszó a vállalkozás lett, az intézmények és az oktatók sikerességét részben a kialakított és múködő kapcsolatokban mérik, az intézmények pedig folyamatos partnerkeresésben vannak. Az intézmények a képzési portfóliójukban a vállalkozásfejlesztés, az e-kormányzat, valamint az információtechnológia vonalat erôsítik. Ez természetesen a műszaki és természettudományos területen érzékelhető leginkább. A Tallinni Egyetem vezető szerepét e folyamatban ez indokolja. E modellekben az egyetemi könyvtárak szerepe is felértékelődik, hiszen már nemcsak az intézmények belsô kutatói, illetve tanulmányaikat folytató rétegének igényeit kell megfelelően szolgálniuk, hanem az intézményi tudástérképet reprezentálva kifelé is nyitottnak kell lenniük.

Magyarországon az ezredfordulót követően több tanulmány is megjelent a témában, ezek elsősorban közgazdasági oldalról vizsgálták az egyetemek és az ipar kapcsolatát, és mutatták be a tudás keletkezését, típusait és transzfer folyamatait a triple helix modelbben, a felsorolt szereplők (felsőoktatási intézmény, magánszektor, valamint az állam) között. Varga Attila 2004-ben - Florax, R. 1992-ben megjelent tanulmánya ${ }^{3}$ alapján - úgy fogalmaz, hogy a felsőoktatási intézményekben dolgozók vagy a tanul- 


\section{NEMES LÁSZLÓ}

mányaikat folytatók vásárlásai - az úgynevezett kiadási hatás - mellett a tudáshatás, azaz a felsőoktatási intézményből a magánszektor felé áramló tudományos, mûszaki, technológiai vagy gazdasági tudás hat leginkább az intézmények környezetében működő cégekre. ${ }^{4}$ E megállapítást magam is elfogadom, kiegészítve azzal, hogy mindezeken túl az intézmények kapcsolati hálót, valamint viselkedési és problémamegoldási formákat is közvetítenek, amelyek szintén a tudástranszfer részei. E publikációban Varga négyféle tudásáramlási módot különböztet meg:

1. publikálás, szakirodalmi közlemények, szabadalmak révén terjedő eredmények;

2. személyek formális vagy informális kapcsolatai révén létrejövő tudástranszfer az egyetemi és vállalati szereplők között, ebben mind a vezetői szintű, mind a munkavállalók elhelyezkedésén alapuló kapcsolatok benne vannak;

3. tudásdiffúzió, azaz formálisan az egyetemekről értékesített tudás révén;

4. a felsőoktatási intézmények fizikai létesítményeinek (pl. laboratórium és a könyvtár) használata, valamint véleményem szerint, a könyvtár esetében az ahhoz kapcsolódó szolgáltatások igénybevétele révén.

Mindezeket a későbbiekben bemutatott módszerek és eljárások alapján még kiegészítem két típussal:

1. a formális oktatásban való részvétel, amely lehetséges hallgatói oldalról, azaz a cégek vesznek igénybe továbbképzéseket, illetve lehetséges oktatói oldalról, amikor céges szereplőket vonnak be az oktatásba, óratartás, értékelés vagy gyakorlat biztosítása révén;

2. megrendelő típus, amikor a felsőoktatási intézmény kutatási irányát a magánszektorból érkező megbízások határozzák meg.

A társadalomtudományok több - általában interdiszciplináris - tudománya is leírja az intézmények és környezetük kapcsolatát, gazdasági, menedzsment, illetve marketing szempontból. A kapcsolatok lehetőségeinek szempontjairól Inz̨elt Annamária 2004-ben a Közgazdasági Szemlebben megjelent tanulmánya ad követhető csoportosítási lehetőséget. ${ }^{5}$ Eszerint az egyetemi-ipari interakciók szintjei és típusai a következők lehetnek:

a. A vállalati alkalmazottak és az egyetemek közti ad hoc megbeszélések;

b. Vállalati alkalmazottak egyetemi előadásai;

c. Egyetemi oktatók előadásai cégek számára;

d. Az egyetemi oktatók és vállalati alkalmazottak rendszeres (informális) megbeszélései szakmai találkozókon, konferenciákon, szemináriumokon; e. Egyetemi kutatási eredmények (szabadalmak) ad hoc jellegű megvásárlása;

f. Egyetemi oktatók rendszeres alkalmazása szakértőként;

g. Vállalati alkalmazottak továbbképzése egyetemi kutatók által;

h. Vállalati alkalmazottak továbbképzése egyetemi oktatók által;

i. Egyetemi kutatók és vállalati alkalmazottak közös publikációi; 
TRANSZFEREK ÉS A KÖNYVTÁR SZEREPE A FELSŐOKTATÁS ÉS A CÉGES SZEKTOR...

j. A PhD- és mesterkurzusok egyetemi és vállalati alkalmazottak közös vezetésével;

k. Egyetemi és vállalati alkalmazottak közös szellemi tulajdonjogai;

1. A speciális egyetemi/vállalati berendezésekhez való hozzáférés a tulajdonos engedélyével vagy anélkül;

m. Egyetemi kutatóhelyekbe történő vállalati beruházások;

n. Egyetemi kutatási eredmények, szabadalmak rendszeres vásárlása; o. Formalizált K+F együttmúködések, például kutatási szerződések;

p. Formalizált $\mathrm{K}+\mathrm{F}$ együttmúködések, például közös kutatási projektek;

q. Felsőfokú végzettségűek mobilitása az egyetemektől a vállalatok felé, és fordítva;

r. A tudásáramlás a kipörgetett cégek kialakulásával.

Vilmányi Márton 2011-ben a Vezetéstudományban publikált cikkében ${ }^{6}$ ezzel a beosztással párhuzamosan négy fokozatot különít el, amelyek a kapcsolatok és az információáramlás intenzitását jelenítik meg:

1. kutatás-támogatás pénzügyi és fizikai eszközökkel;

2. szerződéses kutatási kooperáció;

3. technológiatranszfer, amely magában foglalja a módszertani megoldások kidolgozását, szakértelem átadását, szabadalom átadását vagy fejlesztését;

4. komplex tudástranszfer együttmúködések, amelyek az előbbieken túl komoly személyes egyeztetéseket, programokat is tartalmaznak mind a cégek, mind a felsőoktatási szereplők (oktatók-kutatók, hallgatók, nem oktató-kutató dolgozók) számára.

Ezek a kutatások azonban egyrészt nem tértek ki külön a bölcsész- és humántudományi területre, hanem az iparra fókuszáltak, elsősorban partnerként, másrészt nem vizsgálták az egyetemi könyvtári hálózatok szerepét.

Mit jelent a digitális transzformáció az oktatás és a kutatás terén? A 2012-es Open Educational Resources (OER) (Nyílt oktatási erőforrások) dekrétum UNESCO általi párizsi elfogadásával ${ }^{7}$ az oktatásról alkotott képünk véglegesen megváltozott. A dekrétum abból indult ki, hogy a nyílt forráskódú szoftverek mintájára lehetséges az oktatáshoz kapcsolódó erőforrások (tananyagok, keretrendszerek, módszertanok, előadók, szellemi termékek) terjesztése, újrafelhasználása. Ezen elgondolás szorosan összefügg a kutatási eredmények nyílt hozzáférésével (open access). Az oktatási tartalmak rendszerezett tároláson alapuló elérhetőségének biztosítása a könyvtárak, illetve más gyűjteménytípusok nélkül nem elképzelhető, ugyanakkor ez maga után vonja, hogy az intézmények átalakulása is szükséges. A digitalizáció számos kihívást jelent a könyvtáraknak. Ezek a következők:

- a tárolási körülmények gyors változása, szoftveres elavulás okozta kihívások,

- hitelességi kihívások,

- a rész-egész, kontextusból való kiemelés kihívása. 


\section{NEMES LÁSZLÓ}

Ahogy a felsőoktatás is egyre több tekintetben változik és szövi át a digitalizáció, az egyetemi gyüjtemények is több szempontból változtak. Ezeket az alábbiak szerint foglalhatom össze a szakirodalom és a saját tapasztalatok alapján:

- A Leoni Egyetemi könyvtárban végzett felmérés eredményei azt mutatják, hogy a nyomtatott gyüjtemények használata csökken azon elektronikus tartalom bősége miatt, amelyet a könyvtár előfizetéssel szerez be. ${ }^{8}$

- Elektronikus oktatási anyagok: az elektronikus tananyagok megalkotása új kihívást és egyben lehetôséget is rejt, a komplex tananyagok tárolásától az egyes tananyag elemek (learning asset), illetve tananyag egységek (learning objects) elérésének biztosításáig.

- A vázolt folyamat során nagy mennyiségben keletkező elektronikus tananyagok speciális, mind technikailag, mind tartalmilag rendkívül szerteágazó műfajt képviselő, erôsen a szürke irodalomba hajló dokumentumtípust alkotnak. Nagy Gyula: A könyvtárak szerepe a digitális és elektronikus tananyagok archiválásában című 2018-as Networkshop-előadásában így fogalmazott: „Archiválásuk számtalan megoldandó, elvi és gyakorlati (pl. menedzsment, informatika) problémát felvet, amelyek egy rész̨e egyébként erösen emlékeztet a hazánkban éppen bimbózó szakasz̧ban lévö internetarchiválás által felvetettekre, hiszen a legfóbb problémát általában a tananyagok internetröl való nyomtalan eltünése jelenti. Emellett a másike legsúlyosabb probléma a belsó, intézmény felé való széles körü és egyenletes láthatóság biztositása, amely az esetek nagy többségében szintén gondot okoz: Nagyon sok esetben az elkészült, kiváló tananyagok nem tudnak eljutni a potenciális célkë̈zönséghez, hiszen a használók nem szereznek róluk tudomást az egységes és központi rendszerbe szervezetlenség miatt."”

- Az elektronikus dokumentumok használatáról több adat van, de ez nem azt jelenti, hogy többet is használják őket. Máshogy tudjuk vizsgálni a digitalizáció miatt a trendeket, az állományalakítás jobban köthető a használathoz.

- Távoli elérés: a könyvtári szolgáltatások azok, amelyek egy felsőoktatási intézmény többi szolgáltatása közül a legkönnyebben elérhetőek távolról, a legkevesebb földrajzi és jogosultsági korlátozással. Ez nemcsak a távoktatást támogatja, hanem az oktatói, illetve kutatói munka távoli pontról történő végzését is. A könyvtárak tárolás, feltárás, szolgáltatás feladathármasa a távoktatáshoz használt virtuális felületeken tárolt tartalmak esetében is olyan hátteret biztosít, amely indokolja e rendszerek jövőbeli kooperációját.

- Az adat mint vagyon jelenik meg, azaz magával vonja, hogy annak gazdálkodási szabályait, menedzsmentjét ki kell dolgozni. A felsőoktatási intézmények középtávon nem tehetik meg, hogy csak kutatási eredményeket tesznek közzé. E feladat véleményem szerint a könyvtárakhoz kell, hogy tartozzon, mivel a tudásvagyon tárolása, leírása és szolgáltatása során kialakított és alkalmazott módszertanok megalapozzák ezt a szerepet, valamint a felsőoktatási intéz- 
TRANSZFEREK ÉS A KÖNYVTÁR SZEREPE A FELSŐOKTATÁS ÉS A CÉGES SZEKTOR...

mények struktúrájában elfoglalt helyzetük lehetôvé teszi, hogy ezt intézményi szinten tegyék meg.

- Az adatok mennyisége és minősége szükségessé teszi a mesterséges intelligencia eszközként történő felhasználását.

\section{Összegzés és további irányok.}

A bevezetőben megfogalmazott három kérdésre adott válaszok alapján megállapítható, hogy a felsőoktatás előállít adatot, információt és tudást egyaránt, amelyek áramlásának szintjeit több tudomány is vizsgálta. Bizonyított az is, hogy a digitális átállás nemcsak technikailag hatott az oktatásra, hanem 2012 óta annak erőforrásait is a nyilt hozzáférésű szoftverekhez hasonlóan kezelhetjük. Mindezek mellett kérdés, hogy az egyes szereplők között milyen módon történik ennek az áramlása, melyek azok az útvonalak, amelyeket használunk? Doktori kutatásom ezen ösvényeket vizsgálja, amelynek első lépéseként azok azonosítása történt.

Az általam - nyilvánosan elérhető szolgáltatás, illetve szervezeti leírások, bemutatók, szervezeti és múködési szabályzatok alapján - vizsgált hazai, illetve nemzetközi - Amerikai egyesült államokbeli Eastern Illinois University, egyesült királyságbeli University College London, valamint észtországi Tallinni Egyetem - intézményi gyakorlat azt mutatja, hogy az alábbi transzfer ösvények léteznek:

- a végzett hallgatók által hordozott tudás;

- ötletlaborok, hallgatói innovációs versenyek;

- publikációk, ez a kategória magában foglalja az írott anyagokat, az audiovizuális anyagokat és a konferencia megjelenéseket is;

- kutatási együttmúködések;

- konzultációs szolgáltatások biztosítása;

- szabadalmak;

- egyetemi cégek létrehozása;

- egyetemi tananyagok kurzusok, távoktatási értékesítése (MOOC, blended learning keretében).

Annak érdekében, hogy mérni tudjuk a felsőoktatás és a céges szektor közötti kapcsolat minőségét és intenzitását ezen ösvények meghatározására szükségünk van. A következő lépés ezek intézményi összehasonlítása, illetve a felek általi használatának mérése.

\section{Jegyzetek és irodalom}

1. A Debreceni Egyetem harmadik missziós tevékenysége. Forrás: https://unideb.hu/ node/364 [2020. június 26.]

2. VARGA Attila - PARAG Andrea: Egyetemi tudástranszfer és a nemzetközi kutatási hálózatok szerkezete. = Közgazdasági Szemle, 56. évf. 4. sz. 2009. 343-358. p. 


\section{NEMES LÁSZLÓ}

3. FLORAX, Raymond: The University: A regional booster? Economic impacts of academic knowledge infrastructure. Aldershot, Avebury, 1992.

4. VARGA Attila: Az egyetemi kutatások regionális gazdasági hatásai a nemzetközi szakirodalom tükrében. = Közgazdasági Szemle, 51. évf. 3. sz. 2004. 259-275. p.

5. INZELT Annamária: Az egyetemek és a vállalkozások kapcsolata az átmenet idején. = Közgazdasági Szemle, 51. évf. 9. sz. 2004. 870-890. p.

6. VILMÁNYI Márton: Egyetemi-ipari együttmúködések a kapcsolatmarketing nézőpontjából. = Vezetéstudomány, 42. évf. 1. sz. 2009. 52-63. p.

7. UNESCO's mandate in OER. Forrás: https://en.unesco.org/themes/building-knowledgesocieties/oer [2020. június 26.]

8. RODRÍGUEZ-BRAVO, Blanca - RODRÍGUEZ-SEDANO, Francisco: Trends in library collection circulation in spanish universities: the case of the University of León. = Library Resources \& Technical Services, Vol. 60. No. 4. 2016. 248-258. p. Forrás: https://doi. org/10.5860/lrts.60n4.248 [2020. június 26.]

9. NAGY Gyula: A könyvtárak szerepe a digitális és elektronikus tananyagok archiválásában. Networkshop 2018. Forrás: https://doi.org/10.31915/NWS.2018.13 [2020. június 26.]

Nemes László - 2010-ben szerzett diplomát az ELTE informatikus könyvtáros szakán, 2013ban pedig felsőoktatás- és tudománymenedzsment szakon. 2016-ban sikeres államvizsgát tett levéltár mesterszakon. Az ELTE BTK Irodalomtudományi Doktori Iskola Könyvtártudományi Doktori Programjának doktorandusz hallgatója. Az ELTE Könyvtári Nap főszervezője, valamint részt vett az ELTE és a Lett Állami Egyetem által Rigában megrendezett BOBCATSSS 2018 konferencia szervezésében. 2009-től a Magyar Információtudományi Alapítvány kuratóriumi elnöke. 2018 szeptemberétől a Pázmány Péter Katolikus Egyetem megbízott oktatója. Jelenleg a Digitális Jólét Nonprofit Kft.-nél digitális tudástár fejlesztőként dolgozik, korábbi munkahelyein is digitális tartalmak szolgáltatási rendszereivel foglalkozott e-learning, illetve egyetemi tudásközpontok számára. 